\title{
Correcting the Stress-Strain Curve in Hot Compression Process to High Strain Level
}

Y.P. LI, E. ONODERA, H. MATSUMOTO, and A. CHIBA

DOI: $10.1007 / \mathrm{s} 11661-009-9843-\mathrm{Z}$

(C) The Minerals, Metals \& Materials Society and ASM International 2009

\section{Erratum to: METALLURGICAL AND MATERIALS \\ TRANSACTIONS A, Vol. 40A, No. 4, April 2009, pp. $982-90$ \\ DOI: $10.1007 / \mathrm{s} 11661-009-9783-7$}

IN Table I of the original article, the weight percentages of $\mathrm{P}$ and $\mathrm{S}$ are incorrect. The correct weight percent of $\mathrm{P}$ is 0.002 , and the correct weight percent of $\mathrm{S}$ is 0.0047 .

Y.P. LI, Researcher, E. ONODERA, Researcher, H. MATSUMOTO, Assistant Professor, and A. CHIBA, Professor, are with the Institute of

Materials Research, Tohoku University, Sendai, Japan. Contact e-mail: a.chiba@imr.tohoku.ac.jp

The online version of the original article can be found under doi: 10.1007/s11661-009-9783-7.

Article published online March 13, 2009 